Current Science International

Volume: 10 | Issue: 01| Jan. - March| 2021

\author{
EISSN:2706-7920 ISSN: 2077-4435 \\ DOI: $10.36632 / \mathrm{csi} / 2021.10 .1 .14$ \\ Journal homepage: www.curresweb.com \\ Pages: 148-154
}

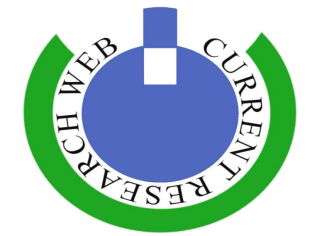

\title{
Effect of Spraying Some Amino Acids, Vitamin B Complex and Boron on Growth and Vine Nutritional Status of Superior Grapevines
}

\author{
Farouk H. Abdelaziz', Faissal F. Ahmed ${ }^{1}$, Ahmed M.K. Abdel Aal ${ }^{1,2}$, Alaa A.B. \\ Masoud $^{3}$ and Safwat-Manar M. ${ }^{1}$
}

${ }^{1}$ Hort. Dept. Fac. of Agric. Minia Univ., Egypt.

${ }^{2}$ Faculty of Meteorology, Environment and Arid Land Agriculture, King Abdulaziz University, Jeddah, Saudi Arabia

${ }^{3}$ Pomology Dept. Fac. of Agric. Assiut Univ., Egypt.

Received: 27 December 2020 Accepted: 10 March $2021 \quad$ Published: 20 March 2021

\begin{abstract}
The effect of single and combined application of one of the three amino acids namely (glutamic, glycine and aspartic acid) at $250 \mathrm{ppm}$ from each, vitamin $\mathrm{B}$ complex $\left(\mathrm{B}_{1}+\mathrm{B}_{2}+\mathrm{B}_{6}+\mathrm{B}_{12}\right)$ at $100 \mathrm{ppm}$ and boric acid at $0.05 \%$ on yield and berry quality of Superior grape cv. were investigated during 2017 and 2018 seasons. Results showed that, single and combined applications of one of three amino acids as well as vitamin B complex and boric acid were very effective on improving main shoot length, number of leaves/ shoot, leaf area, wood ripening coefficient, pruning wood weight / vine, cane thickness, chlorophyll A, chlorophyll B, total chlorophylls, total carotenoids, N, P, K, Mg, Zn, $\mathrm{Fe}$ and $\mathrm{Mn}$ of Superior grapevines comparing with untreated vines. The application of amino acids was more effective than the application of vitamin B and boric acid in this respect AT three sprays (at growth start, just after berry setting and one month later) with a mixture containing $250 \mathrm{ppm}$ glutamic acid plus $100 \mathrm{ppm}$ vitamin B complex and $0.05 \%$ boric acid proved to be very effective in enhancing growth and vine nutritional status of Superior grapevine.
\end{abstract}

Keywords: amino acids, vitamin B complex, boric acid, growth, vine nutritional status

\section{Introduction}

An outstanding effect on growth and vine nutritional status was noticed in Superior grapevines due to using some amino acids, vitamin B and boron. This is due to the positive effect of some amino acids, vitamin B complex and boron on growth and vine nutritional status.

Amino acids as organic nitrogenous compounds are the building blocks in the synthesis of proteins, which are formed by as process in which Ribosome's catalyze the polymerization of amino acids Davies, 1982 and Raskin (1992). Several hypotheses have been proposed explain for the role of amino acids in plant. Available evidence suggests several alternative routes of ethylene and IAA synthesis in plants, starting from amino acids Hashimoto and Yamada (1994); Ahmed and Abd ElHameed (2003) Ahmed et al., 2007; Amin (2007); Seleem- Basma and Abd El-Hameed (2008) and Sayed- Heba (2010).

Vitamin B is responsible for enhancing amino acids biosynthesis, carbohydrates, plant pigments and cell division. Those vitamins B are responsible for enhancing uptake of water and nutrient and increasing tolerance of plant to all stresses. Using vitamins especially vitamin B was very effective in enhancing growth and vine nutritional status in different grapevine cvs. (Samiullah et al., 1988; ElKady- Hanaa, 2011; Madian and Refaai, 2011; Uwakiem, 2011; Abd El-Hameed, 2012; Abdelaal, 2012 ; Ahmed et al., 2012 and Ibrahiem- Rehab, 2012).

Boron plays an important role in the extension of plant cell walls through its association with cell wall pectin's (Banik and Sen, 1997 and Perica et al., 2001). It is also known that the role of boron in Corresponding Author: Farouk H. Abdelaziz, Hort. Dept. Fac. of Agric. Minia Univ., Egypt. 
plant metabolism including many physiological aspects such as nucleic acid metabolism, protein and natural hormone biosynthesis, building and translocation of carbohydrates, photosynthesis, cell division, cell wall synthesis, membrane function and water uptake and pollen germination (Pibleam and Kirkby 1983; Gupta et al., 1985; Blevins and Lukaszweski, 1998) Previous studies supported the beneficial effect of using boron via chelated or sulphate form on growth and vine nutritional status in different grapevine cvs (Amin, 2007; Ahmed, et al., 2007; Abd El-Gaber- Nermean , 2009; El- Sawy, 2009; Abd El-Wahab, 2010; El- Kady- Hanaa, 2011; Abdelaal, 2012; Nikkah et al., 2013 and Mohamed, 2014b).

The target of this study was examining the effect of spraying three amino acids namely (glutamic acid, glycine and aspartic acid) vitamin $\mathrm{B}$ complex $\left(\mathrm{B}_{1}+\mathrm{B}_{2}+\mathrm{B}_{6}+\mathrm{B}_{12}\right)$ and boron on growth traits and vine nutritional status of Superior grapevines.

\section{Material and Methods}

This study was carried out during 2017 and 2018 seasons on 90 uniform in vigour 6- years old Superior grapevines grown in a private vineyard located at Talla village, Minia district, Minia Governorate where soil texture is clay, well drained and water table was not less than two meters deep.

All the selected vines are planted at 1.5 x 3.0 meters apart. The chosen vines ( 90 vines) were pruned during the last week of December in both seasons using cane pruning method with the assistance of Gable supporting system. Bud load / vine were 96 buds for all the selected vines on the basis of eight fruiting cans $\mathrm{x}$ ten buds plus eight renewal spurs $\mathrm{x}$ two buds. Except those vines dealing with the present treatments foliar application of amino acids, vitamin B and boric acid. All selected vines (90 vines) received the recommended horticultural practices which are commonly used in the vineyard.

This study included fifteen treatments containing single of combined application of three amino acids (i.e., glutamic acid, glycine and aspartic acid), vitamin $\mathrm{B}$ complex $\left(\mathrm{B}_{1}+\mathrm{B}_{2}+\mathrm{B}_{6}+\mathrm{B}_{12}\right)$ and boron acid in additions to the untreated vines (control).

1- Untreated vines (Control).

2- Spraying $250 \mathrm{ppm}$ glutamic acid.

3- Spraying $250 \mathrm{ppm}$ glycine.

4- Spraying $250 \mathrm{ppm}$ aspartic acid.

5- Spraying $100 \mathrm{ppm}$ vitamin $\mathrm{B}\left(\mathrm{B}_{1}+\mathrm{B}_{2}+\mathrm{B}_{6}+\mathrm{B}_{12}\right)$.

6- Spraying $0.05 \%$ boric acid.

7- Spraying a mixture of $250 \mathrm{ppm}$ glutamic acid $+100 \mathrm{ppm}$ vitamin B complex.

8- Spraying a mixture of $250 \mathrm{ppm}$ glycine $+100 \mathrm{ppm}$ vitamin B complex.

9- Spraying a mixture of $250 \mathrm{ppm}$ aspartic acid $+100 \mathrm{ppm}$ vitamin $\mathrm{B}$ complex.

10- Spraying a mixture of $250 \mathrm{ppm}$ glutamic acid $+0.05 \%$ Boric acid.

11 - Spraying a mixture of $250 \mathrm{ppm}$ glycine $+0.05 \%$ Boric acid.

12- Spraying a mixture of $250 \mathrm{ppm}$ aspartic acid $+0.05 \%$ Boric acid.

13- Spraying a mixture of $250 \mathrm{ppm}$ glutamic acid $+100 \mathrm{ppm}$ vitamin B complex $+0.05 \%$ Boric acid.

14- Spraying a mixture of $250 \mathrm{ppm}$ glycine acid $+100 \mathrm{ppm}$ vitamin B complex $+0.05 \%$ Boric acid.

15- Spraying a mixture of $250 \mathrm{ppm}$ aspartic acid $+100 \mathrm{ppm}$ vitamin $\mathrm{B}$ complex $+0.05 \%$ Boric acid.

The experiments were conducted as complete randomized block design (Rangaswamy, 1995) was followed where the experiment consisted of fifteen treatments and each treatment was replicated on 6 vines.

The selected vines received three sprays during the growth season. The $1^{\text {st }}$ time at $1^{\text {st }}$ week of March, just after berry setting, the $2^{\text {nd }}$ time during the $1^{\text {st }}$ week of April and the $3^{\text {rd }}$ time was one month later $\left(1^{\text {st }}\right.$ week of May).

Triton $\mathrm{B}$ as a wetting agent was added to all spraying solutions at $0.05 \%$. Spaying was done till run off (2 liters/ vine). Control treatment was carried out by spraying water only.

During both of studied seasons, the following measurements were recorded: 
1- Vegetative growth characteristics namely main shoot length $(\mathrm{cm})$, number of leaves/ shoot, leaf area $(\mathrm{cm})^{2}$ (Ahmed and Morsy, 1999) wood ripening coefficient (Bourad, 1966), wood weight $(\mathrm{kg}$.) and cane thickness $(\mathrm{cm})$

2- Leaf chemical components namely chlorophyll A, chlorophyll B, total chlorophylls, total carotenoids (mg/ g F.W.) (Von - Wesststein 1957), N, P, K, Mg (as \%) Zn, Fe and Mn (as ppm) in leaves (Cottenie et al., 1982 and Summer, 1985).

\section{Statistical analysis.}

The obtained data were tabulated and statistically analyzed according to (Snedecor and Cochran, 1967 and Mead et al., (1993). Differences between treatment means were compared by revised L.S.D. test at 5\% level of probability according to Steel and Torrie, (1984).

\section{Results}

\subsection{Vegetative growth characteristics:}

Data in Table (1) clearly show that single and combined application of some amino acids (glutamic acid, glycine and aspartic acid), vitamin $\mathrm{B}$ complex $\left(\mathrm{B}_{1}+\mathrm{B}_{2}+\mathrm{B}_{6}+\mathrm{B}_{12}\right)$ and boron acid on the six growth traits of Superior grapevines during 2017 and 2018 seasons. It is clear from obtained data that single and combined applications of the amino acids namely $250 \mathrm{ppm}$ glutamic acid, 250 ppm glycine and $250 \mathrm{ppm}$ aspartic acid, $100 \mathrm{ppm}$ vitamin B complex and $0.05 \%$ boric acid significantly stimulated the six growth characteristics namely (main shoot length, number of leaves shoot, leaf area, wood ripening coefficient, pruning wood weight and cane thickness) comparing with the check treatment.

Table 1: Effect of single and combined of applications of some amino acids (glutamic acid, glycine and aspartic acid), vitamin $\mathrm{B}\left(\mathrm{B}_{1}+\mathrm{B}_{2}+\mathrm{B}_{6}+\mathrm{B}_{12}\right)$ and boric acid on some vegetative growth characteristics of Superior grapevine during 2017 and 2018 seasons

\begin{tabular}{|c|c|c|c|c|c|c|c|c|c|c|c|c|}
\hline \multirow[t]{2}{*}{ Treatments } & \multicolumn{2}{|c|}{$\begin{array}{l}\text { Main shoot } \\
\text { length }(\mathrm{cm})\end{array}$} & \multicolumn{2}{|c|}{$\begin{array}{c}\text { No. of } \\
\text { leaves / } \\
\text { shoot } \\
\end{array}$} & \multicolumn{2}{|c|}{$\begin{array}{l}\text { Leaf area } \\
\quad(\mathrm{cm}) 2\end{array}$} & \multicolumn{2}{|c|}{$\begin{array}{c}\text { Wood } \\
\text { ripening } \\
\text { coefficient }\end{array}$} & \multicolumn{2}{|c|}{$\begin{array}{c}\text { Pruning } \\
\text { wood } \\
\text { weight (kg.) } \\
\end{array}$} & \multicolumn{2}{|c|}{$\begin{array}{c}\text { Cane } \\
\text { thickness } \\
(\mathrm{cm}) \\
\end{array}$} \\
\hline & 2017 & 2018 & 2017 & 2018 & 2017 & 2018 & 2017 & 2018 & 2017 & 2018 & 2017 & 2018 \\
\hline 1-Control & 115.0 & 116.0 & 17.0 & 17.0 & 98.5 & 99.0 & 0.67 & 0.68 & 1.95 & 1.98 & 1.05 & 1.08 \\
\hline $\begin{array}{l}\text { 2-Glutamic acid at } 250 \\
\text { ppm }\end{array}$ & 118.0 & 118.5 & 21.0 & 22.0 & 103.8 & 104.2 & 0.80 & 0.82 & 2.18 & 2.20 & 1.16 & 1.17 \\
\hline 3- Glycine at $250 \mathrm{ppm}$ & 117.5 & 118.0 & 20.0 & 21.0 & 102.0 & 103.5 & 0.77 & 0.80 & 2.10 & 2.15 & 1.14 & 1.15 \\
\hline $\begin{array}{l}\text { 4-Aspartic acid at } 250 \\
\text { ppm. }\end{array}$ & 117.0 & 117.5 & 19.0 & 20.0 & 101.2 & 102.0 & 0.75 & 0.77 & 2.06 & 2.09 & 1.13 & 1.14 \\
\hline 5- Vitamin B at $100 \mathrm{ppm}$ & 116.2 & 117.0 & 18.0 & 19.0 & 100.5 & 101.0 & 0.70 & 0.72 & 2.00 & 2.05 & 1.11 & 1.12 \\
\hline 6- Boric acid at $0.05 \%$ & 115.6 & 116.3 & 18.0 & 19.0 & 99.2 & 99.8 & 0.68 & 0.70 & 1.98 & 2.00 & 1.09 & 1.10 \\
\hline $\begin{array}{l}\text { 7-Glutamic acid + } \\
\text { vitamin B }\end{array}$ & 127.0 & 128.2 & 26.0 & 27.0 & 111.5 & 113.0 & 0.87 & 0.88 & 2.38 & 2.40 & 1.25 & 1.26 \\
\hline 8- Glycine + vitamin B & 125.0 & 126.5 & 25.0 & 26.0 & 110.0 & 111.0 & 0.86 & 0.87 & 2.35 & 2.37 & 1.22 & 1.24 \\
\hline $\begin{array}{l}\text { 9-Aspartic acid + } \\
\text { vitamin B }\end{array}$ & 124.0 & 125.0 & 24.0 & 25.0 & 108.4 & 109.0 & 0.85 & 0.86 & 2.32 & 2.35 & 1.21 & 1.22 \\
\hline $\begin{array}{l}\text { 10-Glutamic acid + } \\
\text { Boric acid }\end{array}$ & 122.0 & 124.0 & 23.0 & 24.0 & 107.0 & 107.8 & 0.83 & 0.85 & 2.29 & 2.32 & 1.20 & 1.21 \\
\hline 11- Glycine + Boric acid & 121.0 & 122.2 & 22.0 & 23.0 & 105.2 & 106.0 & 0.81 & 0.83 & 2.25 & 2.30 & 1.18 & 1.20 \\
\hline $\begin{array}{l}\text { 12-Aspartic acid + Boric } \\
\text { acid }\end{array}$ & 118.8 & 119.2 & 21.0 & 22.0 & 104.0 & 105.0 & 0.81 & 0.82 & 2.20 & 2.22 & 1.17 & 1.18 \\
\hline $\begin{array}{l}\text { 13-Glutamic acid + } \\
\text { vitamin B + Boric acid }\end{array}$ & 133.0 & 134.2 & 29.0 & 31.0 & 114.8 & 116.0 & 0.92 & 0.93 & 2.44 & 2.48 & 1.30 & 1.31 \\
\hline $\begin{array}{l}\text { 14- Glycine + vitamin B } \\
+ \text { Boric acid }\end{array}$ & 130.5 & 132.6 & 27.0 & 29.0 & 113.0 & 114.0 & 0.90 & 0.92 & 2.41 & 2.43 & 1.29 & 1.30 \\
\hline $\begin{array}{l}\text { 15-Aspartic acid + } \\
\text { vitamin B + Boric acid }\end{array}$ & 129.0 & 131.0 & 26.0 & 27.0 & 112.0 & 113.5 & 0.89 & 0.90 & 2.39 & 2.41 & 1.27 & 1.28 \\
\hline New L.S.D at $5 \%$ & 0.9 & 1.1 & 1.0 & 1.0 & 1.1 & 1.2 & 0.02 & 0.03 & 0.06 & 0.07 & 0.04 & 0.05 \\
\hline
\end{tabular}


Application of amino acids namely (glutamic acid, glycine and aspartic acid) each at $250 \mathrm{ppm}$ in the same order was significantly superior than using $100 \mathrm{ppm}$ vitamin B superior than $0.05 \%$ boric acid. In enhancing these growth characteristics. Combined application of Amino acids, vitamin B and boric acid were significantly favorable than using each item separately. The maximum values were recorded on the vines that received three sprays of a mixture of $250 \mathrm{ppm}$ glutamic acid, $100 \mathrm{ppm}$ vitamin B complex and $0.05 \%$ boric acid. The lowest values were recorded on the untreated vines. These results were true during 2017 and 2018 seasons.

\subsection{Leaf chemical composition;}

Data in Tables $(2,3)$ clearly show that single and combined applications of the amino acids namely (glutamic acid, glycine and aspartic acid) each at $250 \mathrm{ppm}, 100 \mathrm{ppm}$ vitamin B complex and $0.05 \%$ boron acid was significantly accompanied with enhancing chlorophylls A, B, total chlorophylls, total carotenoids, $\mathrm{N}, \mathrm{P}, \mathrm{K}, \mathrm{Mg}, \mathrm{Zn}, \mathrm{Fe}$ and $\mathrm{Mn}$ in the leaves rather than check treatment. The promotion was significantly associated with using glutamic acid, glycine, aspartic acid, vitamin B complex and boric acid in descending order. Using amino acids significantly superior than vitamin B complex superior than boric acid in descending order in enhancing such leaf chemical composition. Combined application of some, amino acids, vitamin B and boric acid were significantly favorable than using each item separately. The maximum values of chlorophyll A ( $3.66,3.70 \mathrm{mg} / \mathrm{g} \mathrm{F}$.W.), chlorophyll B $(1.55,1.60 \mathrm{mg} / \mathrm{g} \mathrm{F} . W$.$) , total chlorophylls (5.21,5.30 \mathrm{mg} / \mathrm{g} \mathrm{F}$.W.), total carotenoids $(1.44,1.50 \mathrm{mg} / \mathrm{g} \mathrm{F} . \mathrm{W}),. \mathrm{N}(2.03,2.08 \%), \mathrm{P}(0.30,0.31 \%), \mathrm{K}(1.40,1.42 \%), \operatorname{Mg}(0.78,0.80 \%)$, $\mathrm{Zn}(64.0,65.0 \mathrm{ppm}), \mathrm{Fe}(62.8,63.7 \mathrm{ppm}), \mathrm{Mn}(62.5,63.0 \mathrm{ppm})$ were recorded in the leaves of the vines that received three sprays of a mixture of $250 \mathrm{ppm}$ glutamic acid, $100 \mathrm{ppm}$ vitamin B complex and $0.05 \%$ boric acid during 2017 and 2018 seasons, respectively. The lowest values were recorded on untreated vines. These results were true during both two seasons.

Table 2: Effect of single and combined of applications of some amino acids (glutamic acid, glycine and aspartic acid), vitamin $B\left(B_{1}+B_{2}+B_{6}+B_{12}\right)$ and boric acid on some photosynthetic pigments and percentages of $\mathrm{N}$ and $\mathrm{P}$ in the leaves of Superior grapevine during 2017 and 2018 seasons.

\begin{tabular}{|c|c|c|c|c|c|c|c|c|c|c|c|c|}
\hline \multirow[t]{2}{*}{ Treatments } & \multicolumn{2}{|c|}{$\begin{array}{c}\text { Chlorophyll } \\
\text { A } \\
\text { (mg/g F.W.) } \\
\end{array}$} & \multicolumn{2}{|c|}{$\begin{array}{c}\text { Chlorophyll } \\
\text { B } \\
\text { (mg/g F.W.) }\end{array}$} & \multicolumn{2}{|c|}{$\begin{array}{c}\text { Total } \\
\text { chlorophylls } \\
\text { (mg/g F.W.) }\end{array}$} & \multicolumn{2}{|c|}{$\begin{array}{c}\text { Total } \\
\text { Carotenoids } \\
\text { (mg/g F.W.) }\end{array}$} & \multicolumn{2}{|c|}{$\begin{array}{r}\text { Leaf } \\
\text { N\% }\end{array}$} & \multicolumn{2}{|c|}{$\begin{array}{l}\text { Leaf } \\
\text { P\% }\end{array}$} \\
\hline & 2017 & 2018 & 2017 & 2018 & 2017 & 2018 & 2017 & 2018 & 2017 & 2018 & 2017 & 2018 \\
\hline 1-Control & 2.92 & 2.99 & 1.11 & 1.13 & 4.03 & 4.12 & 1.01 & 1.02 & 1.61 & 1.60 & 0.14 & 0.16 \\
\hline $\begin{array}{l}\text { 2-Glutamic acid at } 250 \\
\text { ppm }\end{array}$ & 3.17 & 3.19 & 1.29 & 1.31 & 4.46 & 4.50 & 1.19 & 1.21 & 1.77 & 1.78 & 0.22 & 0.23 \\
\hline 3- Glycine at 250 ppm & 3.13 & 3.16 & 1.24 & 1.28 & 4.37 & 4.44 & 1.14 & 1.18 & 1.72 & 1.75 & 0.20 & 0.21 \\
\hline $\begin{array}{l}\text { 4-Aspartic acid at } 250 \\
\text { ppm. }\end{array}$ & 3.10 & 3.14 & 1.21 & 1.24 & 4.31 & 4.38 & 1.11 & 1.13 & 1.68 & 1.69 & 0.18 & 0.19 \\
\hline 5- Vitamin B at $100 \mathrm{ppm}$ & 3.05 & 3.11 & 1.18 & 1.20 & 4.23 & 4.33 & 1.08 & 1.09 & 1.66 & 1.67 & 0.17 & 0.18 \\
\hline 6- Boric acid at $0.05 \%$ & 2.98 & 3.06 & 1.15 & 1.18 & 4.13 & 4.24 & 1.04 & 1.08 & 1.63 & 1.64 & 0.15 & 0.17 \\
\hline $\begin{array}{l}\text { 7-Glutamic acid + vitamin } \\
\text { B }\end{array}$ & 3.42 & 3.48 & 1.45 & 1.46 & 4.87 & 4.94 & 1.34 & 1.35 & 1.91 & 1.93 & 0.28 & 0.29 \\
\hline 8- Glycine + vitamin B & 3.36 & 3.40 & 1.41 & 1.42 & 4.77 & 4.82 & 1.31 & 1.32 & 1.88 & 1.90 & 0.27 & 0.28 \\
\hline $\begin{array}{l}\text { 9-Aspartic acid + vitamin } \\
\text { B }\end{array}$ & 3.32 & 3.35 & 1.39 & 1.40 & 4.71 & 4.75 & 1.29 & 1.30 & 1.85 & 1.87 & 0.26 & 0.27 \\
\hline $\begin{array}{l}\text { 10-Glutamic acid + Boric } \\
\text { acid }\end{array}$ & 3.30 & 3.33 & 1.35 & 1.38 & 4.65 & 4.71 & 1.24 & 1.27 & 1.84 & 1.86 & 0.25 & 0.26 \\
\hline 11- Glycine + Boric acid & 3.24 & 3.27 & 1.33 & 1.35 & 4.57 & 4.62 & 1.23 & 1.24 & 1.83 & 1.84 & 0.24 & 0.25 \\
\hline $\begin{array}{l}\text { 12-Aspartic acid + Boric } \\
\text { acid }\end{array}$ & 3.20 & 3.22 & 1.30 & 1.32 & 4.50 & 4.54 & 1.20 & 1.22 & 1.80 & 1.81 & 0.23 & 0.24 \\
\hline $\begin{array}{l}\text { 13-Glutamic acid + } \\
\text { vitamin B + Boric acid }\end{array}$ & 3.66 & 3.70 & 1.55 & 1.60 & 5.21 & 5.30 & 1.44 & 1.50 & 2.03 & 2.08 & 0.30 & 0.31 \\
\hline $\begin{array}{l}\text { 14- Glycine + vitamin B + } \\
\text { Boric acid }\end{array}$ & 3.59 & 3.61 & 1.50 & 1.53 & 5.09 & 5.14 & 1.40 & 1.43 & 1.99 & 2.00 & 0.29 & 0.29 \\
\hline $\begin{array}{l}\text { 15-Aspartic acid + vitamin } \\
\text { B + Boric acid }\end{array}$ & 3.50 & 3.54 & 1.48 & 1.50 & 4.98 & 5.04 & 1.38 & 1.40 & 1.93 & 1.95 & 0.28 & 0.29 \\
\hline New L.S.D at 5\% & 0.04 & 0.05 & 0.04 & 0.04 & 0.06 & 0.07 & 0.04 & 0.03 & 0.07 & 0.08 & 0.01 & 0.02 \\
\hline
\end{tabular}


Table 3: Effect of single and combined of applications of some amino acids (glutamic acid, glycine and aspartic acid), vitamin $\mathrm{B}\left(\mathrm{B}_{1}+\mathrm{B}_{2}+\mathrm{B}_{6}+\mathrm{B}_{12}\right)$ and boric acid on the leaf content of $\mathrm{K}$ and $\mathrm{Mg}$ (as \%) and Zn, Fe and Mn (as ppm) of Superior grapevine during 2017 and 2018 seasons.

\begin{tabular}{|c|c|c|c|c|c|c|c|c|c|c|}
\hline \multirow{2}{*}{ Treatments } & \multicolumn{2}{|c|}{$\begin{array}{c}\text { Leaf } \\
\mathbf{K}(\%) \\
\end{array}$} & \multicolumn{2}{|c|}{$\begin{array}{c}\text { Leaf } \\
\operatorname{Mg}(\%)\end{array}$} & \multicolumn{2}{|c|}{$\begin{array}{c}\text { Leaf Zn } \\
(\mathrm{ppm})\end{array}$} & \multicolumn{2}{|c|}{$\begin{array}{c}\text { Leaf Fe } \\
(\mathrm{ppm})\end{array}$} & \multicolumn{2}{|c|}{$\begin{array}{l}\text { Leaf Mn } \\
\text { (ppm) }\end{array}$} \\
\hline & 2017 & 2018 & 2017 & 2018 & 2017 & 2018 & 2017 & 2018 & 2017 & 2018 \\
\hline 1-Control & 1.12 & 1.13 & 0.50 & 0.50 & 50.5 & 50.8 & 49.5 & 49.8 & 51.4 & 51.6 \\
\hline 2-Glutamic acid at $250 \mathrm{ppm}$ & 1.25 & 1.26 & 0.61 & 0.62 & 53.0 & 53.2 & 52.1 & 52.3 & 54.2 & 54.4 \\
\hline 3- Glycine at $250 \mathrm{ppm}$ & 1.22 & 1.24 & 0.59 & 0.60 & 52.0 & 52.4 & 51.2 & 51.3 & 53.0 & 53.4 \\
\hline 4-Aspartic acid at $250 \mathrm{ppm}$. & 1.19 & 1.21 & 0.58 & 0.59 & 51.5 & 51.9 & 50.6 & 50.8 & 52.6 & 53.0 \\
\hline 5- Vitamin B at $100 \mathrm{ppm}$ & 1.17 & 1.19 & 0.55 & 0.56 & 51.0 & 51.5 & 50.0 & 50.4 & 52.1 & 52.6 \\
\hline 6- Boric acid at $0.05 \%$ & 1.15 & 1.17 & 0.53 & 0.54 & 50.8 & 51.0 & 49.7 & 50.1 & 51.9 & 52.0 \\
\hline 7-Glutamic acid + vitamin B & 1.36 & 1.37 & 0.70 & 0.71 & 58.2 & 59.0 & 57.2 & 58.0 & 59.3 & 60.0 \\
\hline 8- Glycine + vitamin B & 1.33 & 1.34 & 0.67 & 0.68 & 57.0 & 58.0 & 56.1 & 57.0 & 58.2 & 59.1 \\
\hline 9-Aspartic acid + vitamin B & 1.30 & 1.31 & 0.65 & 0.66 & 55.4 & 56.0 & 54.3 & 55.0 & 56.5 & 57.0 \\
\hline 10-Glutamic acid + Boric acid & 1.30 & 1.31 & 0.65 & 0.66 & 55.4 & 55.6 & 54.0 & 54.5 & 56.0 & 57.0 \\
\hline 11- Glycine + Boric acid & 1.27 & 1.28 & 0.63 & 0.65 & 54.0 & 54.8 & 53.1 & 53.7 & 55.1 & 55.8 \\
\hline 12-Aspartic acid + Boric acid & 1.25 & 1.27 & 0.61 & 0.63 & 53.4 & 54.0 & 53.3 & 53.0 & 54.5 & 55.0 \\
\hline $\begin{array}{l}\text { 13-Glutamic acid + vitamin B + Boric } \\
\text { acid }\end{array}$ & 1.40 & 1.42 & 0.78 & 0.80 & 64.0 & 65.0 & 62.8 & 63.7 & 62.5 & 63.0 \\
\hline 14- Glycine + vitamin B + Boric acid & 1.39 & 1.41 & 0.75 & 0.77 & 62.0 & 63.0 & 61.0 & 62.0 & 61.0 & 62.1 \\
\hline $\begin{array}{l}\text { 15-Aspartic acid + vitamin B + Boric } \\
\text { acid }\end{array}$ & 1.37 & 1.38 & 0.72 & 0.73 & 60.0 & 60.9 & 59.0 & 59.8 & 60.0 & 60.5 \\
\hline New L.S.D at 5\% & 0.04 & 0.05 & 0.03 & 0.03 & 2.0 & 2.2 & 2.0 & 2.1 & 1.9 & 2.1 \\
\hline
\end{tabular}

\section{Discussion}

The promoting effect of amino acids on growth and vine nutritional status of Superior grapevine might be attributed to the favourable effects of these organic substances on enhancing the biosynthesis of proteins through polymerization of amino acids ethylene, $\mathrm{GA}_{3}$, plant pigments ( Davies, 1982).

These results are in concordance with those obtained by (Abdelaal et al., 2013; Gad ElKareem and Abada , 2014; Mohamed 2014a and El- Khawaga, 2014). The promoting effect of vitamin $\mathrm{B}$ and boron on the growth and vine nutritional status could be attributed to their positive action on amending the vines with their requirements from different boron, vitamin B and amino acids. These results regarding the effect of antioxidants are in agreement with those obtained ( ElKady- Hanaa, 2011; Madian and Refaai, 2011, Uwakiem, 2011; Abd El-Hameed, 2012; Abdelaal, 2012; Ibrahiem- Rehab, 2012; Nikkah et al., 2013 and Mohamed , 2014b).

\section{Conclusion}

Under the conditions of this experiment and the resembling conditions, it is advised to spray Superior grapevine three times at (growth start, just after berry setting and one month later) with a mixture of $250 \mathrm{ppm}$ glutamic acid plus, $100 \mathrm{ppm}$ vitamin B complex plus $0.05 \%$ boric acid.

\section{References}

Abd El- Hameed, H.M., 2012. Using silicon, Boron and folic acid to promote yield quantitatively and qualitatively of early Superior grapevines. Minia J. of Agric. Res. \& Develop., 32(5):869-886.

Abd El- Wahab, M.H., 2010. Relation of fruiting in Superior grapevines with spraying sulphur, magnesium, zinc and boron. M. Sc. Thesis. Fac. of Agric. Minia Univ. Egypt.

Abd El-Gaber- Nermean, M.E.H., 2009. Response of Red Roomy grapevines to foliar application of boron, magnesium and zinc. M. Sc. Thesis Fac. of Agric. Minia Univ. Egypt. 
Abdelaal, A.M.K., F.F. Ahmed, and E.E.H. Abdelaal, 2013. The stimulative effects of using some nutrients and antioxidants on growth, nutritional status and yield of Thompson seedless grapes. Hort. Science J. of Suez Canal Univ., 1: 322-329.

Abdelaal, E.E.H.A., 2012. The Synergistic effects of using some nutrients as well as antioxidant substances on growth, nutritional status and productivity of Thompson seedless grapevines grown under Sohag region. Ph. D. Thesis Fac. of Agric. Sohag Univ. Egypt.

Ahmed, A.H. and H.M. Abd El- Hameed, 2003. Growth, uptake of some nutrients and productivity of Red Roomy vines as affected by spraying of some amino acids, magnesium and boron. Minia J. of Agric. Res. \& Develop., 723 (4): 649 - 666.

Ahmed, F. F and M. H. Morsy, 1999. A new method for measuring leaf area in different fruit species. Minia. J. of Agric .Rec. \& Dev.19: 97 - 105.

Ahmed, F.F., A.M.K. Abdelaal and E.E.H. Abd Elaal, 2012. Promoting productivity of Thompson seedless grapevines by application of some antioxidants and nutrients. Minia J. of Agric. Res. \& Develop., 32(3): 527-542.

Ahmed, F.F., M.A. Mohamed, A.M.K. Abd El-Aal and M.M. Amin, 2007. Response of Red Roomy grapevine to application of amino acids and some micronutrients. The Third Conference for Sustainable Agricultural Development, Al-Fayoum, 12-14 November pp,150-170.

Amin, M. M. A., 2007. Response of Red Roomy grapevines to application of amino acids and some micronutrients. M. Sc. Thesis Fac. of Agric. Minia Univ. Egypt.

Banik, B.C. and S.K. Sen, 1997. Effect of Zinc, iron and boron spray along with urea on N, P and K content in leaf and shoot of mango cv. Fazli. Environment and Ecology, 18(3): 696-698.

Blevins, D.G. and M.K. Lukaszweski, 1998. Boron in plant structure and function. Annual Plant Physio. Plant. Mol. Biol. 489-481

Bouard, J., 1966. Recharches, physiologiques sur la vigen at en particulier sur laoudment des serments. Thesis Sci. Nat. Bardeux France, p.34.

Cottenie, A., A. Cerloo, M. Verloo, M. Velghe, and R. Camerlynck, 1982. Chemical analysis of Plant and Soil. Ghent. Belgium. Laboratory of Analytical and agrochemistry State Univ. pp. 200- 210.

Davies, D.D., 1982. Physiological aspects of protein turmour Encyclo. Plant Physiol., 13 A, Eds Boulter, D. and B Partier Soringer verlag, Berlin, New York, pp. 190- 228.

El- Sawy, Y.A.E., 2009. Attempts for breaking dormancy and improving fruiting of Superior grapevines. Ph. D. Thesis Fac. of Agric. Minia Univ. Egypt.

El-Kady-Hanaa, F. M., 2011. Productive performance of Thompson seedless grapevines in relation to application of some antioxidants, magnesium and boron. M. Sc. Thesis Fac. of Agric. Minia Univ. Egypt.

El-Khawaga, A.S., 2014. Impact of vitamin B and C, glutamic acid and silicon on fruiting of Superior grapevines. World Rural Observations. 6(4): 57-62.

Gad El- Kareem, M.R. and M.A.M. Abada, 2014. Trials for promoting productivity of Flame seedless grapevines. J. of Biol. Chem. Environ. Sci. 9(1): 35-40.

Gupta, M.C., Y.W. Hama, C.A. Campbell, A.J. Leyshon and V. Nicholoichnk, 1985. Boron toxicity and deficiency Canadian J. Soil Sci. 65:381-409.

Hashimoto, T. and Y. Yamada, 1994. Alkaloid biosynthesis Molecular aspects Ann. Res. Plant Physio. Plant. Md. Bio., Pp. 243-257.

Ibrahim- Rehab, G., 2012. Behaviour of Thompson seedless grapevines to spraying of some vitamin. M. Sc. Thesis Fac. of Agric. Minia Univ. Egypt.

Madian, A.M. and M.M. Refaai, 2011. The synergistic effects of using B vitamin with the two amino acids tryptophane and methionene in Thompson seedless grapevines. Minia J. of Agric. Res. \& Develop., 31(3): 445-454.

Mead, R., R.N. Currnow and A.M. Harted, 1993. Statistical Methods in Agricultural and Experimental Biology. Second Ed. Chapman \& Hall, London, pp. 54-60.

Mohamed, T.M.M., 2014a. Relation of fruiting in Superior grapevines with spraying salicylic acids and boron. M. Sc. Thesis Fac. of Agric. Minia Univ. Egypt.

Mohamed, T.M.M., 2014b. Relation of fruiting in Superior grapevines with spraying salicylic acids and boron. M. Sc. Thesis Fac. of Agric. Minia Univ. Egypt. 
Nikkhah, R., H. Nafar, S. Rastgoo and M. Dorostkar, 2013. Effect of foliar application of boron and zinc on qualitative and quantitative fruit characteristics of grapevines (Vitis vinifera L.) Intl $\mathrm{J}$. Agric. Crop Sci., 6 (9): 485-192.

Perica, S. N. Bellaloui, C. Gerve, H. Hu. and P.H. Broan, 2001. Boron transport and soluble carbohydrate concentrations in olive. Amer. Soc. Hort. Sci., 126" 291-296.

Pilbeam, D.J. and E.A. Kirkby, 1983. The physiological role of boron in plants. J. Plant Nutrition 6 : 563-582.

Rangaswamy, R., 1995. Randomized Complete Block Design. In: A Text Book of Agricultural Statistics. "New Age International Publishers, pp 281-309.

Raskin, I., 1992. Role of salicylic acid in plant. Ann. Rev. Plant Physio. Plant. Mol. Bio. 43: 439-463.

Samiulleh, S.A., M.M. Ansori and R.K. Afridi, 1988. B- vitamin in relation to crop productivity Indian, Rev. Life Sci., $8: 51-74$.

Sayed- Heba, F.I., 2010. Effect of stimulant aminoquelant-Ca and Zinc on yield and berries quality of Thompson seedless grapevines M. Sc. Thesis Fac. of Agric. Minia Univ. Egypt.

Seleem- Basma, M. and H.M. Abd El- Hameed, 2008. Effect of the stimulant aminoqualent Ca on yield and berries quality of Thompson seedless grapevines. Minia J. of Agric. Res. \& Develop. Vol. 28 No.1 pp. 13-21

Snedecor, G.W. and G.W. Cochran, 1967. Statistical Methods (sixth ed.) Iowa State Univ. Press U.S.A. pp. 20-25.

Steel, R.G.D. and J.H. Torrie, 1984. Principles and Procedures of Statistics. MC-Grow Hill Book Co., Singapore, 2. Ed 633pp.

Summer, M.E., 1985. Diagnosis and Recommendation Integrated system (DRIS) as a guide to orchard fertilization. Hort. Abst. 55(8): 7502.

Uwakiem, M. Kh., 2011. Effect of some organic, bio and slow release $\mathrm{N}$ fertilizers as well as some antioxidants on vegetative growth, yield and berries quality of Thompson seedless grapevines. $\mathrm{Ph}$. D, Thesis. Fac. of Agric. Minia Univ. Egypt.

Von-Wettstein, D.V., 1957. Chlroophyll- Lethalc under submikroshopishe formilkechrel der plastiden cell, prp. Trop. Res. Amer. Soc. Hort. Sci., 20 pp. 427-433. 